\title{
Examination of Gifted Students' Internet / Game Addiction and School Social Behaviors
}

\author{
Ayşin Kaplan Sayı ${ }^{1}$, Filiz Şahin ${ }^{2}$ \\ ${ }^{1}$ Assistant Professor, Bahçesehir University, Faculty of Educational Sciences, Gifted and Talented Education Program, Istanbul. \\ ${ }^{2}$ Maths Teacher, Irmak Schools, Istanbul. \\ * This article is produced from the master's thesis "The Effect of Internet Use and Computer Game Addiction on School Social Behaviors \\ of Gifted Children" carried out by the second author with consultancy of the first author.
}

\begin{abstract}
Internet and games can have some adverse effects if used unconsciously. Especially for gifted students, internet and games can be risky and result in addiction due to their cognitive and social characteristics. Since the game and internet addiction conduce to social problems as well. In this vein, the purpose of the study is to examine the internet and game addiction levels of gifted students and their school social behaviors in terms of gender and age variables. In addition, the relationship between computer addiction scale scores and school social behavior scale scores are also examined within the scope of the study. Descriptive correlational survey method is used in the study.The sample is comprised of 157 gifted students and 16 teachers of them. Convenient sampling was used in the study.In conclusion, internet and game addiction scores of the gifted boys in the study were higher than those of girls. On the other hand, in terms of school social behaviors, the findings showed that gifted girls achieved higher scores than boys. Additionally, it is also observed that gifted children aged 10 and over got higher scores from internet and game addiction while the School social behavior did not show a significant difference according to the age variable. As the internet and game addiction scores of the gifted children increased, their school social competence, weakened. On the other hand, it was seen that the increase in the gifted children's internet / game addiction led to an increase in their antisocial behaviors.
\end{abstract}

Keywords: Gifted students, internet addiction, game addiction, social behavior, school social behavior

\section{InTRODUCTION}

With the revolutionary advances in the information technologies field and increasing number of people benefiting from them, the internet has become an indispensable part of our lives. The widespread use of the internet has turned people into active users substantially involved in online communication and enjoying their freedom of communication (Timisi, 2003). Thanks to the ever-growing use of the internet, communication has been enabled in multiple platforms and through digital personal blogs and web groups (Sicilia\&Palazon, 2008 ). While internet usage has reached $79 \%$ in Turkey; the rate of households with internet access throughout the country is 90.7\% (TURKSTAT, 2020). In this sense, the internet continues to expand into every segment of the world as a rapidly growing network. It is now an indispensable communication tool for the state, universities, companies and individuals (Özen, Gülaçtı,\&Çakıl1,2004).

The widespread use of the internet and computer technologies has also led to the introduction of digital games into people's lives. Digital games have become a powerful industry over the years since they produced the first commercial computer games in 1970. According to the statistics, digital games sector has achieved a revenue of 24.5 billion dollars in 2013 and one billion users (Irmak \&Erdoğan, 2016). Previous studies have evidenced that people prefer to play computer games in order to relax, get away from themselves, assume different identities or escape from the hectic pace of their daily routines (Sucu, 2012). Digital games are also reported to have certain benefits in the development of visual memory, critical thinking, computer literacy, spatial skills, geometry and mathematics development, hand eye coordination, creativity and imagination. However, there are also certain drawbacks associated with digital games. For example, they bring about aggression, introversion, addiction to the virtual world, violence and various health problems (Ankara Development Agency, 2016; Horzum, 2011; Özhan, 2011; Yavuz, 2018).

Children are one of the groups adversely affected by computer games and unconscious use of the internet

Corresponding Author e-mail: aysinkaplansayi@gmail.com https://orcid.org/0000-0002-8186-4593

How to cite this article: Sayı AK, Şahin F, (2021). Examination of Gifted Students' Internet / Game Addiction and School Social Behaviors. Pegem Journal of Education and Instruction, Vol. 11, No. 4, 2021, 33-43

Source of support: Nil

Conflict of interest: None.

DOI: 10.47750/pegegog.11.04.04

Received: 21.05.2021

Accepted: 10.07.2021 Publication: 01.10.2021 
(Gürbüz, Yıldırım,\&Özden, 2001). Considering that they can be overly indulged in computer games and are not always capable of making informed choices regarding the amount of play time, they may be prone to problems in their social environment, relationships with family and friends, and schoolwork. The more one plays computer games and identifies with their content, the more likely it is that it will turn into addiction. As can be observed in any type of addiction, the affected person may experience communication problems (National Institute on Media and the Family, 2005). The concept of Internet addiction is a relatively new and often undiagnosed clinical condition that causes individuals to lose control over their internet use, to a degree that causes problems related to work and social life (Young, 2007).

Giftedness is defined as a broad concept which is a synthesis of special skills such as motivation, creativity, intelligence and dedication to the task (Renzulli, 1999; Sternberg, 2003;Ülger\&Çepni,2020). According to Ministry of National Education Science and Art Centers regulation, gifted individuals are defined as "individuals who have a faster learning pace than their peers, show better creative, artistic and leadership capacity, have special academic ability, can understand abstract ideas, like to act independently in their areas of interest, and exhibit a high level of performance" (MoNE, 2016, p.450). However, the fact that gifted and talented individuals possess advanced cognitive skills and outperform their peers regarding cognitive dimensions does not necessarily mean that they won't have social and emotional problems (Clark, 2008). That is, they cannot show the same level of development in emotional, social and physical areas (Silverman, 1993). When the inherent characteristics of gifted children are considered, it can be claimed that they may tend to develop addiction to the internet and computer games (Clark, 2008; Say1, 2013). Therefore, it is likely that gifted children's school social behaviors may also be negatively affected by this situation. In line with this, the current study examines gifted children's internet/game addiction and the relationship between their internet/game addiction and school social behaviors.

As a matter of fact, the findings of a recent study documented that $46.79 \%$ of the gifted students in the study might be possible addicts, while $12.11 \%$ of them are found to be truly addicted (Usta, 2016). Gifted children may have problems in their social lives as they are often mentally occupied, perfectionist and quick on the draw; devote themselves to things they do; analyze situations from different perspectives; and generally feel comfortable in mental pursuits due to their physical and mental asynchrony (Clark, 2008; Kokot, 2012; Silverman, 1993), which can explain why these individuals can be a high-risk group regarding internet and game addiction. Additionally, gifted students become more intertwined with technology and especially internet/games partly due to the widespread STEM studies and failure to adequately address the social-emotional needs of the gifted children in Turkey (Elcik, 2015). This situation may increase internet and game addiction among gifted students and be considered another risk factor (Ogurlu, Kahraman,\&Kayaalp, 2021). The relevant literature indicates that game addiction is related to the lack of some coping skills in children avoiding or using these skills (Kiraly et al., 2018; Şenormanc1, Şenormanc1, Güçlü,\& Konkan, 2014). In addition, there is a negative relationship between game addiction and mental health, especially between anxiety, stress and depression (Loton, Borkoles, Lubman, \& Polman, 2016; Stockdale \&Coyne, 2018). Internet and game addiction also harms gifted children's social, emotional and academic development (Ogurlu, Kahraman,\&Kayaalp, 2021; Yalçın \&Duran, 2017; Yavuz, 2018) and decreases their quality of life (Yalçın, Güvener, \& Kasar, 2020). As a result, gifted children, who can contribute considerably to the advancement and welfare of the society with their creative productivity, may not fulfill their potentials due to internet and game addiction.

Gifted students were found to show higher levels of addiction than their peers (Usta, 2016). Previous research has indicated that gifted male students have higher scores on the game addiction scale compared to female students counterparts (Usta, 2016; Yalcin, Güvener, \&Kasal, 2020; Yavuz, 2018) and thus, they are more addicted (Yalcin, Güvener,\&Kasal, 2020; Yavuz, 2018). It has also been evidenced that internet/game addiction levels of gifted students increase with age (Usta, 2016; Yavuz, 2018). Among the gifted students, those who mostly use the internet for social sharing, chatting, gaming, listening to music and watching movies and videos have higher scores on the internet addiction scale than the students who use the internet for homework and research (Yavuz, 2018). Similarly, the majority of gifted high school students' use of internet consists of engagement in social media though they are expected to benefit from the internet mostly for research purposes (Bozdağ \&Ağaoğlu, 2019).In addition, as the internet addiction levels of gifted students increase, their computer game and computer addiction levels also increase (Ayhan Bostanc1, 2020). When the school social behavior is handled, according to literature the school social skills of children related to school social behaviors differ between genders. Female students are better in terms of interpersonal relations and self-control skills while negative social behaviors and antisocial-aggressive behaviors are more common among male students (Bilgiç, 2007; Olweus, 2005; Totan, 2008;Türky1lmaz \&Pekdoğan,2019). Besides related to age variable, it is expected that students' school social behavior develop with age that underlines their adaptation and social learning (Bandura\&Walters, 1963) and development of social problem solving skills (Ar1\&Yaban, 2012; Erwin, 1993). When the relationship is focused on between internet and game addiction and social behavior, as the computer, internet and 
computer game addiction levels of gifted children increase, their social skill levels (Ayhan Bostanc1, 2020) and wellbeing also decrease (Yalcin, Güvener \& Kasar, 2020).

Studies so far have examined the attitudes of gifted children towards computer and computer lessons (Taşdemir, 2017), internet usage levels (Bozdağ \&Ağaoğlu, 2019), social media usage motivations (Köroglu, 2014), the effect of game preferences on success (Üstünel, 2008) and their views on digital games (Koçak, 2019). There are five studies conducted directly on internet and game addiction, in which internet addiction levels of gifted students in terms of different variables (Usta, 2016), internet game addiction levels of gifted and non-gifted children (Ogurlu, Kahraman, \&Kayaalp, 2021), gifted and non-gifted adolescents' internet addiction and cyberbullying levels (Sureada Garcia, López Penádes, Rodriguez Rodriguez, \& Sureda Negre, 2020), internet and game addiction and perceived social support levels (Yavuz, 2018), and the relationship between internet game addiction and wellbeing (Yalcin, Güvener, \&Kasar, 2020) were examined. Regarding the limited number of studies on gifted children's internet and game addiction and lack of studies focusing on the relationship between gifted children's internet and game addiction and school social behaviors, the current study is intended to contribute to the relevant body of literature and address the research gap.

With its findings regarding gifted students, this study is intended to guide administrators, teachers, families and experts, who can be better informed about their gifted students and tailor the curriculum according to their needs and based on empirical evidence. For example, school counselors can carry out intervention programs regarding internet/game addiction risk and improve gifted students' school social behaviors.

In this context, the general purpose of the study is to examine the internet and internet game addiction levels of gifted students and their school social behaviors in terms of gender and age variables. Since previous research reported that gender is an important variable both in computer and game addiction (Usta, 2016; Yalcin, Güvener, \& Kasal, 2020; Yavuz, 2018) and in school social behavior (Bilgiç, 2007; Olweus, 2005; Totan, 2008; Türkyılmaz and Pekdoğan, 2019). Age is another important variable both in computer and game addiction Usta,
2016; Yavuz, 2018) and in school social behavior (Ar1 \&Yaban, 2012; Bandura\&Walters, 1963; Erwin, 1993;). In addition, the relationship between computer addiction scale scores and school social behavior scale scores was also examined within the scope of the study. In this vein the main guiding questions of the study are as follows:

- Dogifted students' internet and game addiction scores differ significantly in terms of the students' gender and age?

- Do gifted students' school social behavior scores differ significantly in terms of the students' gender and age?

- Is there a relationship between the gifted students' computer addiction scale scores and school social behavior scale scores?

\section{Method}

\section{Research Design}

This study was designed as a descriptive correlational survey research. "Descriptive studies are studies that aim to describe a past or present situation as it is. The situation, individual or object subject to research is tried to be defined as it is. No effort is made to change or influence them in any way" (Karasar, 2014, p. 77).

\section{Population and Sample}

The universe of this study consists of the students who were diagnosed as gifted and their teachers in the 2017-2018 academic years in Istanbul. The sample is comprised of 157 gifted students aged 8-12 who lived in Istanbul in the 20172018 academic year receiving education in three different enrichment courses, and 16 teachers who taught them in these courses. Convenient sampling method was used in the study. In convenient sampling method, data are obtained from individuals who are ready to participate in the study (Kothari, 2004). Information about the students and teachers having participated in the study is presented in Table 1.

As seen in Table 1, 101 of 157 gifted students are male and 56 are female. Of the 157 gifted students, 55 are 8-year-old, 61 to the 9 -year-old, and 41 to the 10 -and-above group. While 10 of the teachers are female, and 6 are male. Four of these teachers are in the 20-25 age group, four are in the 26-30 age group, five are in the 31-35 age group, and two are in the 35-and-above group.

Table 1: Distribution of the Students and Teachers by Gender and Age.

\begin{tabular}{|c|c|c|c|c|c|c|c|}
\hline $\begin{array}{l}\text { Gender of } \\
\text { Students }\end{array}$ & $f$ & Age of Students & $f$ & $\begin{array}{l}\text { Gender of } \\
\text { Teachers }\end{array}$ & $f$ & Age of Teachers & $f$ \\
\hline Female & 56 & 8 & 55 & Female & 10 & $20-25$ & 4 \\
\hline \multirow[t]{3}{*}{ Male } & 101 & 9 & 61 & Male & 6 & $26-30$ & 5 \\
\hline & & 10 and above & 41 & & & $31-35$ & 5 \\
\hline & & & 73 & & & 35 and above & 2 \\
\hline Total & 157 & & 157 & Total & 16 & & 16 \\
\hline
\end{tabular}




\section{Data Collection Tools}

Data for the study were collected through Personal Information Form developed by the researchers; Computer Addiction Scale for Adolescents developed by Ayas, Çakır and Horzum (2011) and School Social Behavior Scales (SSBS) developed by Merrell (1993) and adapted to Turkish by Yukay-Yüksel (2012).

Addiction Scale for Adolescents. The scale consists of 54 items and 2 sub-dimensions.It is a 5-point Likert type. These two sub-dimensions are internet addiction and game addiction. The internal consistency coefficient of the scale was .96 for the first factor; .95 for the second factor, and .95 for the whole scale. In the current study, the Cronbach Alpha value of the scale was calculated as .93 for the first factor, .90 for the second factor, and .91 for the whole scale. This result was consistent with the values of the scale.

School Social Behavior Scales (SSBS).School Social Behavior Scales were developed in five-point Likert type to evaluate the social skills of pre-school and primary school students. The scale is intended to rate students' behaviors in their social and academic environments by their teachers' observations. The scale covers all sub-dimensions in the social skills category and these scales are suitable for use for the sub-scales. The scale consists of 65 items and two forms examining six subcategories under social competence and antisocial behavior subdimensions. The A form, the Social Competence form, includes interpersonal skills, self-management skills and academic skills sub-categories. The B form, Antisocial Behavior Form, consists of hostile / irritable behaviors, antisocial / aggressive behaviors, and demanding / disruptive behaviors sub-categories. Cronbach $\alpha$, Spearman Brown and Guttman Split Half reliability coefficients obtained from subscales vary between .98 and .91. The correlation coefficients obtained from each of the subscales vary between .83 and .100 . According to these results, SSBS was a highly reliable scale (Yukay-Yüksel, 2009). In this study, Cronbach a values calculated for the two scales and their subdimensions were found to vary between .93 and .88 .

\section{Data Collection}

The Computer Addiction Scale for Adolescents was administered to the participant students in the study by the second researcher in their classrooms upon receiving institutional permission. The School Social Behavior Scale was sent to home for the teachers to fill out upon a briefing session where information is given regarding the scale and its application. Although the application time of the first scale varies according to different age groups, it takes 20 to 40 minutes on average. For the second scale, the time that teachers allocate for each student ranges between 10-20 minutes.

\section{Data Analysis}

Data were analyzed by SPSS 21.0 program. Within the scope of the research questions, normality tests were carried out for school social behavior and internet computer game total scores calculated for each student. Shapiro - Wilk normality test results indicated that there was a significant deviation from normality in scale scores $(\mathrm{p}<.05)$. However, when the skewness-kurtosis coefficients were examined, it was observed that the leadership scores of both groups were within the \pm 2 range. School social behavior scale social competence sub dimension (skewness = -.536; kurtosis = -1.0); antisocial behavior subdimension (skewness $=-1.3$; kurtosis $=2.0$ ); internet usage subdimension (skewness $=-.74$; kurtosis $=-$. 88 ); computer game subdimension (skewness $=.83$; kurtosis $=-$. 79) values indicated that the scores obtained met the normality criteria. Thus, descriptive statistical methods were used to evaluate the data. T-Test; One Way Variance Analysis (ANOVA) Test and Scheffe Test were used to compare data. Pearson Correlation Test was conducted to examine the relationship between dependent variables in the study. The findings obtained were evaluated at.05 significance level.

\section{FINDINGS}

Appropriate statistical techniques were used to determine whether the leadership potential scores differ according to certain variables (intelligence, gender, age, type of school, number of siblings, participation in out-of-school activities, economic status and parents' level of education); and the results are presented below.

0As seen in Table 2, according to the results of the independent groups T-Test, the arithmetic means of internet addiction scores, computer game addiction scores and total scores of both dimensions differ significantly in favor of male students $(\mathrm{p}<.01)$ in the Internet and Game Addiction Scale. Based on this finding of the study, it can be concluded that male students are more addicted to the internet and computer games. Considering the arithmetic means of the School Social Behavior Scales scores; a significant difference in favor of girls in all sub-dimensions and total scores $(\mathrm{p}<.01)$ was observed, which indicates that school social adaptation of female students is higher than that of the male ones.

As presented in Table 3, the arithmetic means in the Internet and Game Addiction Scale differ significantly according to the age variable. (Internet addiction: $\mathrm{F}=5.91 ; \mathrm{p}$ $<.01$; Game addiction: $\mathrm{F}=2.92 ; \mathrm{p}<.05$; Total: $\mathrm{F}=4.40 ; \mathrm{p}<.01)$. Based on Levene's test results ( $\mathrm{LF}=0.35 ; 05)$, it was decided to perform a post-hoc Scheffe test to determine between-groups mean differences. Scheffe test results showed that the mean scores of the 10 -or-above group ( $\mathrm{X}=57.80$, ss $=22.25$ ) were significantly higher than the mean scores of 8 year-olds $(\mathrm{X}=$ 44.13 , ss $=16.41)$ and 9 year-olds $(X=54.31$, sd $=22.70)$ in the internet addiction sub-dimension. This finding reveals that students aged 10 or above are more addicted to the internet compared to other age groups. In the game addiction subdimension, although the students aged 10 or more had the 
Table 2: Independent Groups T-Test Results Regarding Whether Internet and Game Addiction and School Social Behavior Scores Differ by Gender.

\begin{tabular}{|c|c|c|c|c|c|c|c|c|}
\hline Sub dimensions & Gruplar & $N$ & $\bar{X}$ & $S D$ & $\mathbf{B}$ & $t$ & $d f$ & $p$ \\
\hline Internet Addiction & $\begin{array}{l}\text { Male } \\
\text { Female }\end{array}$ & $\begin{array}{l}101 \\
56\end{array}$ & $\begin{array}{l}56.72 \\
42.41\end{array}$ & $\begin{array}{l}23.61 \\
11.24\end{array}$ & $\begin{array}{l}2.33 \\
1.52\end{array}$ & 5.11 & 152 & .00 \\
\hline Computer Games Addiction & $\begin{array}{l}\text { Male } \\
\text { Female }\end{array}$ & $\begin{array}{l}101 \\
56\end{array}$ & $\begin{array}{l}52.13 \\
39.32\end{array}$ & $\begin{array}{l}26.52 \\
13.95\end{array}$ & $\begin{array}{l}2.64 \\
1.86\end{array}$ & 3.90 & 154 & .00 \\
\hline $\begin{array}{l}\text { Internet and Computer Games } \\
\text { Addiction in Total }\end{array}$ & $\begin{array}{l}\text { Male } \\
\text { Female }\end{array}$ & $\begin{array}{l}101 \\
56\end{array}$ & $\begin{array}{l}108.92 \\
81.63\end{array}$ & $\begin{array}{l}49.13 \\
23.95\end{array}$ & $\begin{array}{l}4.82 \\
3.14\end{array}$ & 4.61 & 152 & .00 \\
\hline Interpersonal Skills & $\begin{array}{l}\text { Male } \\
\text { Female }\end{array}$ & $\begin{array}{l}101 \\
56\end{array}$ & $\begin{array}{l}53.12 \\
58.03\end{array}$ & $\begin{array}{l}12.62 \\
11.94\end{array}$ & $\begin{array}{l}1.21 \\
1.63\end{array}$ & -2.33 & 155 & .01 \\
\hline Self Management Skills & $\begin{array}{l}\text { Male } \\
\text { Female }\end{array}$ & $\begin{array}{l}101 \\
56\end{array}$ & $\begin{array}{l}37.51 \\
42.84\end{array}$ & $\begin{array}{l}9.90 \\
8.01\end{array}$ & $\begin{array}{l}.98 \\
1.01\end{array}$ & -3.61 & 155 & .00 \\
\hline Academic Skills & $\begin{array}{l}\text { Male } \\
\text { Female }\end{array}$ & $\begin{array}{l}101 \\
56\end{array}$ & $\begin{array}{l}29.90 \\
34.51\end{array}$ & $\begin{array}{l}8.12 \\
6.80\end{array}$ & $\begin{array}{l}.80 \\
.91\end{array}$ & -3.72 & 130 & .00 \\
\hline Social Competence Total & $\begin{array}{l}\text { Male } \\
\text { Female }\end{array}$ & $\begin{array}{l}101 \\
56\end{array}$ & $\begin{array}{l}120.61 \\
135.42\end{array}$ & $\begin{array}{l}30.01 \\
25.63\end{array}$ & $\begin{array}{l}2.92 \\
3.43\end{array}$ & -3.20 & 129 & .00 \\
\hline Hostile-Irritable & $\begin{array}{l}\text { Male } \\
\text { Female }\end{array}$ & $\begin{array}{l}101 \\
56\end{array}$ & $\begin{array}{l}51.82 \\
66.83\end{array}$ & $\begin{array}{l}20.22 \\
6.04\end{array}$ & $\begin{array}{l}2.01 \\
.80\end{array}$ & -6.87 & 128 & .00 \\
\hline Antisocial-Aggressive & $\begin{array}{l}\text { Male } \\
\text { Female }\end{array}$ & $\begin{array}{l}101 \\
56\end{array}$ & $\begin{array}{l}39.60 \\
48.05\end{array}$ & $\begin{array}{l}12.60 \\
4.62\end{array}$ & $\begin{array}{l}1.21 \\
.62\end{array}$ & -5.96 & 139 & .00 \\
\hline Demanding-Disruptive & $\begin{array}{l}\text { Male } \\
\text { Female }\end{array}$ & $\begin{array}{l}101 \\
56\end{array}$ & $\begin{array}{l}33.81 \\
41.80\end{array}$ & $\begin{array}{l}10.93 \\
4.71\end{array}$ & $\begin{array}{l}1.01 \\
.62\end{array}$ & -6.33 & 147 & .00 \\
\hline Antisocial Behavior in Total & $\begin{array}{l}\text { Male } \\
\text { Female }\end{array}$ & $\begin{array}{l}101 \\
56\end{array}$ & $\begin{array}{l}125.3 \\
156.6\end{array}$ & $\begin{array}{l}43.51 \\
14.62\end{array}$ & $\begin{array}{l}4.30 \\
1.91\end{array}$ & -6.59 & 134 & .00 \\
\hline School Social Behavior Scale in Total & $\begin{array}{l}\text { Male } \\
\text { Female }\end{array}$ & $\begin{array}{l}101 \\
56\end{array}$ & $\begin{array}{l}245.91 \\
292.10\end{array}$ & $\begin{array}{l}69.21 \\
35.23\end{array}$ & $\begin{array}{l}6.81 \\
4.70\end{array}$ & -5.52 & 154 & .00 \\
\hline
\end{tabular}

Table 3. Results of One-Way Analysis of Variance (ANOVA) Regarding Whether Internet and Game Addiction and School Social Behavior Scores Differ by Gender.

\begin{tabular}{|c|c|c|c|c|c|c|c|c|c|c|}
\hline Sub dimensions & $\begin{array}{l}\text { Age } \\
\text { Groups }\end{array}$ & $N$ & $X$ & $S D$ & $\begin{array}{l}\text { Squares of } \\
\text { Variances }\end{array}$ & $\begin{array}{l}\text { Sum of } \\
\text { variances }\end{array}$ & $d f$ & $\begin{array}{l}\text { Mean } \\
\text { squares }\end{array}$ & $F$ & $p$ \\
\hline \multirow[t]{4}{*}{ Internet Addiction } & 8 & 55 & 44.13 & 16.41 & Between & 5082.73 & 2 & 2541.3 & 5.91 & .00 \\
\hline & 9 & 61 & 54.31 & 22.70 & Groups & & 154 & 423.7 & & \\
\hline & $\begin{array}{l}10 \text { and } \\
\text { above }\end{array}$ & 41 & 57.80 & 22.25 & $\begin{array}{l}\text { Within } \\
\text { groups }\end{array}$ & 65250.31 & 156 & & & \\
\hline & Total & 157 & 51.61 & 21.26 & Total & 70333.12 & & & & \\
\hline Computer Games & 8 & 55 & 41.61 & 19.62 & Between & 3254.20 & 2 & 1627.16 & 2.92 & .05 \\
\hline \multirow[t]{3}{*}{ Addiction } & 9 & 61 & 49.30 & 24.93 & Groups & & 154 & & & \\
\hline & $\begin{array}{l}10 \text { and } \\
\text { above }\end{array}$ & 41 & 52.83 & 25.41 & $\begin{array}{l}\text { Within } \\
\text { groups }\end{array}$ & 83936.31 & 156 & 545.01 & & \\
\hline & Total & 157 & 47.54 & 23.64 & Total & 87190.55 & & & & \\
\hline Internet and Computer & 8 & 55 & 85.82 & 34.63 & Between & 16455.90 & 2 & 8227.92 & 4.40 & .01 \\
\hline \multirow[t]{3}{*}{ Games Addiction in Total } & 9 & 61 & 103.63 & 47.70 & Groups & & 154 & & & \\
\hline & $\begin{array}{l}10 \text { and } \\
\text { above }\end{array}$ & 41 & 110.64 & 46.72 & $\begin{array}{l}\text { Within } \\
\text { groups }\end{array}$ & 283449.71 & 156 & 1840.50 & & \\
\hline & Total & 157 & 99.25 & 43.81 & Total & 299905.73 & & & & \\
\hline \multirow[t]{5}{*}{ Interpersonal Skills } & 8 & 55 & 53.71 & 12.60 & Between & 344.90 & 2 & 172.42 & 1.01 & .33 \\
\hline & 9 & 61 & 54.23 & 12.73 & Groups & & & & & \\
\hline & 10 and & 41 & 57.24 & 12.21 & Within groups & 24406.61 & 154 & 158.43 & & \\
\hline & above & & & & Total & 24751.52 & & & & \\
\hline & Total & 157 & 54.92 & 12.50 & & & 156 & & & \\
\hline
\end{tabular}




\begin{tabular}{|c|c|c|c|c|c|c|c|c|c|c|}
\hline Sub dimensions & $\begin{array}{l}\text { Age } \\
\text { Groups }\end{array}$ & $N$ & $X$ & $S D$ & $\begin{array}{l}\text { Squares of } \\
\text { Variances }\end{array}$ & $\begin{array}{l}\text { Sum of } \\
\text { variances }\end{array}$ & $d f$ & $\begin{array}{l}\text { Mean } \\
\text { squares }\end{array}$ & $F$ & $p$ \\
\hline \multirow[t]{5}{*}{ Self-Management Skills } & 8 & 55 & 39.80 & 877.31 & Between & 55.86 & 2 & 27.93 & .29 & .74 \\
\hline & 9 & 61 & 38.61 & 10.10 & Groups & & & & & \\
\hline & 10 and & 41 & 39.90 & 10.03 & Within groups & 14365.82 & 154 & 93.25 & & \\
\hline & above & & & 9.63 & Total & & & & & \\
\hline & Total & 157 & 39.43 & & & 14421.74 & 156 & & & \\
\hline \multirow[t]{4}{*}{ Academic Skills } & 8 & 55 & 32.02 & 6.92 & Between & 49.82 & 2 & 24.93 & .38 & .68 \\
\hline & 9 & 61 & 30.81 & & Groups & & & & & \\
\hline & $\begin{array}{l}10 \text { and } \\
\text { above }\end{array}$ & 41 & 32.03 & & $\begin{array}{l}\text { Within groups } \\
\text { Total }\end{array}$ & 10026.13 & 154 & 65.14 & & \\
\hline & Total & 157 & 31.54 & & & 10075.21 & 156 & & & \\
\hline \multirow{5}{*}{$\begin{array}{l}\text { Social Competence } \\
\text { inTotal }\end{array}$} & 8 & 55 & 125.62 & 27.01 & Between & 757.21 & 2 & 378.61 & .43 & .64 \\
\hline & 9 & 61 & 123.83 & & Groups & 133627.13 & & 867.70 & & \\
\hline & 10 and & 41 & 129.35 & 30.02 & Within groups & 134384.32 & 154 & & & \\
\hline & above & 157 & 125.84 & 30.73 & Total & & & & & \\
\hline & Total & & & 29.32 & & & 156 & & & \\
\hline \multirow[t]{5}{*}{ Hostile-Irritable } & 8 & 55 & 60.51 & 1.448 .40 & Between & 1068.72 & 2 & 534.30 & 1.60 & .19 \\
\hline & 9 & 61 & 56.32 & 18.23 & Groups & & & 325.32 & & \\
\hline & 10 and & 41 & 54.03 & 21.69 & Within groups & 50084.10 & 154 & & & \\
\hline & above & & 57.10 & 18.18 & Total & & & & & \\
\hline & Total & 157 & & & & 51152.81 & 156 & & & \\
\hline \multirow[t]{5}{*}{ Self-Management Skills } & 8 & 55 & 39.80 & 877.31 & Between & 55.86 & 2 & 27.93 & .29 & .74 \\
\hline & 9 & 61 & 38.61 & 10.10 & Groups & & & & & \\
\hline & 10 and & 41 & 39.90 & 10.03 & Within groups & 14365.82 & 154 & 93.25 & & \\
\hline & above & & & 9.63 & Total & & & & & \\
\hline & Total & 157 & 39.43 & & & 14421.74 & 156 & & & \\
\hline \multirow[t]{4}{*}{ Academic Skills } & 8 & 55 & 32.02 & 6.92 & Between & 49.82 & 2 & 24.93 & .38 & .68 \\
\hline & 9 & 61 & 30.81 & & Groups & & & & & \\
\hline & $\begin{array}{l}10 \text { and } \\
\text { above }\end{array}$ & 41 & 32.03 & & $\begin{array}{l}\text { Within groups } \\
\text { Total }\end{array}$ & 10026.13 & 154 & 65.14 & & \\
\hline & Total & 157 & 31.54 & & & 10075.21 & 156 & & & \\
\hline \multirow{5}{*}{$\begin{array}{l}\text { Social Competence } \\
\text { inTotal }\end{array}$} & 8 & 55 & 125.62 & 27.01 & Between & 757.21 & 2 & 378.61 & .43 & .64 \\
\hline & 9 & 61 & 123.83 & & Groups & 133627.13 & & 867.70 & & \\
\hline & 10 and & 41 & 129.35 & 30.02 & Within groups & 134384.32 & 154 & & & \\
\hline & above & 157 & 125.84 & 30.73 & Total & & & & & \\
\hline & Total & & & 29.32 & & & 156 & & & \\
\hline \multirow[t]{5}{*}{ Hostile-Irritable } & 8 & 55 & 60.51 & 1.448 .40 & Between & 1068.72 & 2 & 534.30 & 1.60 & .19 \\
\hline & 9 & 61 & 56.32 & 18.23 & Groups & & & 325.32 & & \\
\hline & 10 and & 41 & 54.03 & 21.69 & Within groups & 50084.10 & 154 & & & \\
\hline & above & & 57.10 & 18.18 & Total & & & & & \\
\hline & Total & 157 & & & & 51152.81 & 156 & & & \\
\hline \multirow[t]{5}{*}{ Antisocial-Aggressive } & 8 & 55 & 44.32 & 9.71 & Between & 265.30 & 2 & 132.61 & 1.02 & .32 \\
\hline & 9 & 61 & 41.90 & 11.10 & Groups & & & 126.30 & & \\
\hline & 10 and & 41 & 41.21 & 13.03 & Within groups & 19468.11 & 154 & & & \\
\hline & above & & 42.67 & 112.02 & Total & & & & & \\
\hline & Total & 157 & & & & 19723.50 & 156 & & & \\
\hline \multirow[t]{5}{*}{ Demanding-Disruptive } & 8 & 55 & 37.10 & 8.44 & Between & 19.43 & 2 & 9.71 & .09 & .90 \\
\hline & 9 & 61 & 36.63 & 9.96 & Groups & & & 101.10 & & \\
\hline & 10 and & 41 & 36.23 & 11.92 & Within groups & 15573.30 & 154 & & & \\
\hline & above & & 36.74 & 9.91 & Total & & & & & \\
\hline & Total & 157 & & & & 15592.72 & 156 & & & \\
\hline Antisocial Behavior in & 8 & 55 & 142.02 & 32.23 & Between & 2837.82 & 2 & 1418.93 & .90 & .31 \\
\hline \multirow[t]{3}{*}{ Total } & 9 & 61 & 134.93 & 38.82 & Groups & 233559.10 & & 1516.62 & & \\
\hline & $\begin{array}{l}10 \text { and } \\
\text { above }\end{array}$ & 41 & 131.54 & 46.51 & $\begin{array}{l}\text { Within groups } \\
\text { Total }\end{array}$ & 236397.01 & 154 & & & \\
\hline & Total & 157 & 136.56 & 38.94 & & & 156 & & & \\
\hline School Social Behavior & 8 & 55 & 267.68 & 50.03 & Between & 2381.53 & 2 & 1190.75 & .23 & .76 \\
\hline \multirow[t]{3}{*}{ Scales Total } & 9 & 61 & 258.81 & 65.42 & Groups & 622861.02 & & 4044.58 & & \\
\hline & $\begin{array}{l}10 \text { and } \\
\text { above }\end{array}$ & 41 & 260.84 & 75.91 & $\begin{array}{l}\text { Within groups } \\
\text { Total }\end{array}$ & 625242.54 & 154 & & & \\
\hline & Total & 157 & 262.45 & 63.35 & & & 156 & & & \\
\hline
\end{tabular}


highest average scores, no significant difference was found between three age groups. In terms of the total scores of the whole test, it was found that the mean score of the students aged 10 or more ( $\mathrm{X}=110.64$, ss $=46.72$ ) was significantly higher than the average score of the 8 -year-old age group $(\mathrm{X}=85.82$, sd $=34.63)$. This finding indicates that students aged 10 and above show more internet and game addiction compared to other age groups. Again, as presented in Table 3., the arithmetic averages of the school social behavior scale scores do not significantly differ according to the age variable $(\mathrm{p}<.05)$.

According to the results of the Pearson test presented in Table 4, a moderately significant negative correlation was found between the internet addiction scores and school social behavior scale interpersonal skills sub-dimension $(r=-.54$; $\mathrm{p}$ $<0.001)$; self-management sub-dimension $(r=-.59 ; \mathrm{p}<0.001)$; academic skills sub-dimension $(\mathrm{r}=-. .63 ; \mathrm{p}<0.001)$ and total school social competence sub-dimension ( $r=-.60 ; \mathrm{p}<0.001)$. In the internet and game addiction scale, a highly significant negative correlation was found between the students' internet addiction scores and their school social behavior scale hostile/ irritable behavior sub-dimension scores $(r=-.71 ; \mathrm{p}<0.001)$, demanding/ destructive behavior sub-dimension scores $(\mathrm{r}=$ -. 67; $\mathrm{p}<0.001)$ and antisocial behavior sub-dimensions $(\mathrm{r}=$ -. 70; $\mathrm{p}<0.001)$. A moderately significant negative correlation was found between the students' internet addiction scores and their antisocial / aggressive behavior sub-dimension scores ( $\mathrm{r}$ $=-.59 ; \mathrm{p}<0.001)$.

There was a moderately significant negative correlation between the Internet and Game Addiction Scale game addiction scores and the School Social Behavior Scale interpersonal skills sub-dimension $(\mathrm{r}=-.58$; $\mathrm{p}<0.001)$, selfmanagement sub-dimension $(r=-.62 ; \mathrm{p}<0.001)$; academic skills sub-dimension $(\mathrm{r}=-.67 ; \mathrm{p}<0.001)$. A highly significant negative correlation was found between the subscales of social competence and total social competence $(r=-.63 ; \mathrm{p}<0.001)$. There was a highly significant negative relationship between the Internet and Game Addiction Scale game addiction scores and the School Social Behavior Scale aggressive behavior sub-dimension ( $\mathrm{r}=-.73 ; \mathrm{p}<0.001$ ), anti-social / aggressive behaviors sub-dimension ( $\mathrm{r}=-.69$; $\mathrm{p}<0.001)$, demanding/ destructive behavior sub-dimension $(\mathrm{r}=-.68$; $\mathrm{p}<0.001)$, and total antisocial behavior ( $\mathrm{r}=-.71$; $\mathrm{p}<0.001)$.

While there was a moderately significant negative correlation between the total scores of the Internet and Game Addiction Scale and the interpersonal skills sub-dimension of the school social behavior scale $(\mathrm{r}=-.58$; $\mathrm{p}<0.001)$; a highly significant negative correlation was found between selfmanagement sub-dimension ( $r=-.62$; $\mathrm{p}<0.001)$, academic skills sub-dimension $(\mathrm{r}=-.66 ; \mathrm{p}<0.001)$ and the total school social competence sub-dimension ( $\mathrm{r}=-.63 ; \mathrm{p}<0.001)$. While there was a moderately significant negative correlation between the total scores of the Internet and Game Addiction Scale and the School Social Behavior Scale demanding/ destructive behavior sub-dimension $(\mathrm{r}=-.69$; $\mathrm{p}<0.001)$, a highly significant negative correlation was found between hostile/irritable behavior subscale $(\mathrm{r}=-. .74 ; \mathrm{p}<0.001)$; anti-social / aggressive behaviors sub-dimension $(\mathrm{r}=-.70 ; \mathrm{p}<0.001)$ and total antisocial behavior $(\mathrm{r}=-.72 ; \mathrm{p}<0.001)$.

\section{Discussion}

The current study was carried out to compare the internet and game addiction levels of gifted students and their school social behaviors according to gender and age variables and examine the relationship between the Internet and Game Addiction Scale scores and School Social Behavior Scales scores. When the data obtained in the study were analyzed, it was seen that the internet and game addiction scores of male gifted students were higher than those of female students in terms of sub-dimensions and total scores. The findings of the current study are consistent with those of earlier studies (Doğan, 2013; Morahan-Martin and Schumacher, 2000; Ogurlu, Kahraman, \&Kayaalp, 2021; Usta, 2016; Wang, 2001). One reason for this can be the difference between male and female brains. The testosterone hormone in men helps increase skills in abstract operations, spatial domains, science, mathematics, sports,

Table 4: Results of Pearson Test Analysis between Internet and Game Addiction Scale Scores and School Social Behavior Scale Scores.

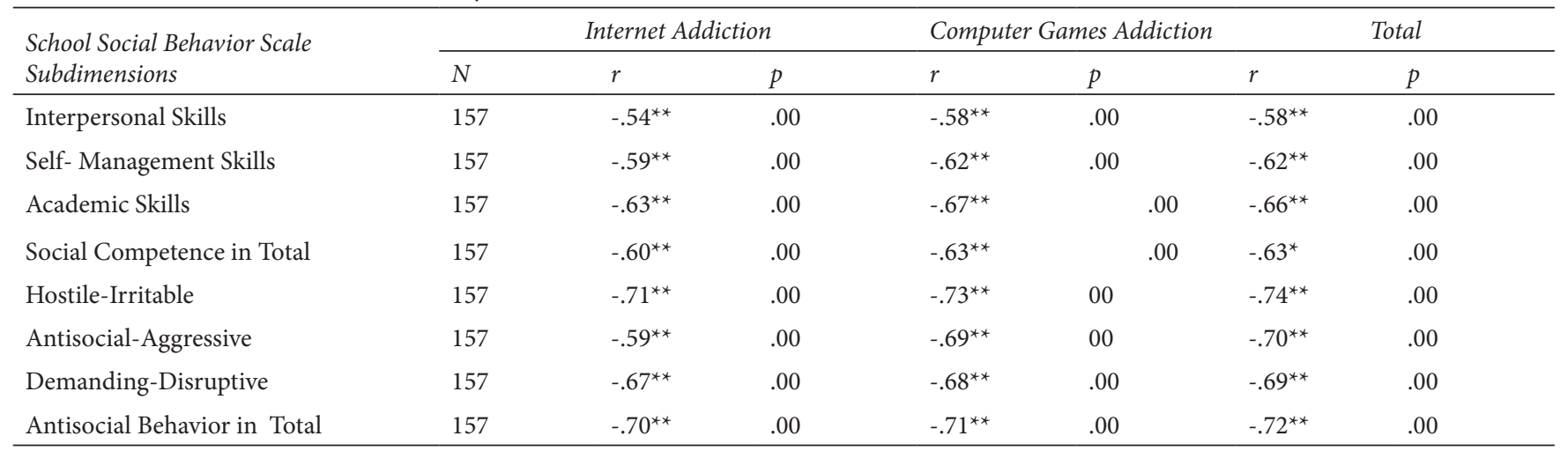


work and computer (Jensen, 2000; cite in Kaplan, 2005), which may cause men to be interested in computers at an earlier age. Another reason may also be that, culturally, it can be easy for male students to reach computer, which is a cause for increasing game addiction. On the other hand, Yavuz (2018) observed that there was no significant difference between male and female students in terms of internet addiction while game addiction scores of male students were higher than female students. This finding may be related to the age scope of the sample. Another study in the literature evidenced that there was not a significant relationship between gender and internet and game addiction (Bayraktar, 2001).

In terms of school social behaviors, it was observed that the female gifted students in the study achieved higher scores than their male counterparts in the sub-dimensions and total scores. It can be concluded based on this finding that the school social adaptation of female gifted students is higher than that of male students. It is of high importance for gifted girls to be approved by their social environments (Davis\&Rimm, 2004). Also, their self-perceptions are shaped by the expectations of their parents, teachers and peers (Bleeker \&Jacobs, 2004; Eccles, 1994; Reis, \&Hebert, 2008). Often, female gifted students tend to hide their potentials for the sake of social acceptance (Silverman, 1993). Based on these findings of the earlier studies in the literature, it can be claimed that female gifted students attach great importance to harmony with the social environment and avoid any behavior that would endanger this harmony. In the literature, there are studies that can confirm this claim, showing that gifted girls outperform boys in social domains (Eren, Ömerelli Çete, Avcil, \& Baykara, 2018; Sevgili Koçak \& Kan, 2019).

The findings of the current study showed that the participants aged 10 and above received higher scores in terms of the internet addiction sub-dimension and total scores compared to the other two age groups, namely 8 -year-olds and 9-year-olds. In the game addiction sub-dimension, no significant difference was observed in terms of age variable, though the students aged 10 or above had the highest average. This situation reveals that students in the age group 10 and above are more addicted to the internet and games compared to other age groups. There are many studies indicating that internet and game addiction in children increases with age (Kisa, 2018; Usta, 2016; Yavuz, 2018). One reason for this situation can be that families intervene and restrict children from using the internet and computers at an early age while children enjoy more freedom and act more independently as they grow older. Another reason why the gifted students aged 10 or above showed more internet and game addiction may be that they may have entered the stage of preadolescence and the level of perceived social support from the family may have decreased (Kuru, 2018). The relevant literature suggests that the psychological adaptation of the gifted is closely related to perceived social support from the family (Dengiz, 2014; Kahriman, 2002; Rinn, Reynolds, \&McQueen, 2011). On the other hand, there are also studies that did not find a significant difference between internet game addiction and age (Ha et al. 2007; Özgün, 2021).

In the current study, the students' school social behaviors did not show a significant difference according to the age variable. Several scholars have also observed that students' social skill scores do not differ according to the grade level. These findings can be explained by the fact that the participant students' ages did not vary significantly (Ayhan Bostanc1, 2020; Kisa, 2018).

A moderate negative correlation was found between the computer addiction scale scores of gifted students and their School Social Behavior Scales interpersonal skills subdimension. A highly significant negative correlation was found between the self-management sub-dimension, academic skills sub-dimension and total social competence. Based on these findings of the study, it can be concluded that as the internet and game addiction scores of gifted children increase, their interpersonal skills, self-management, academic skills and social competencies, which are important components of school social competence, weaken. Previous studies have also found a negative relationship between computer addiction and social skills (Ayhan Bostanc1, 2020; Caplan, 2005; Çeliker, 2020; Kisa, 2018), which can be caused by the fact that children who already have problems with their social skills tend to use the internet and play games more. Gifted children not only think differently but also feel different (Silverman, 1993). Therefore, gifted children are more affected compared to their peers when they encounter negative attitudes. In that sense, it is of great importance to create positive and supportive environments where gifted children can feel comfortable and express their feelings freely (Marland, 1972; cite in Webb, Meckstroth, \& Tolan, 1994). Students who have difficulties in social skills use the internet and play computer games for a number of reasons including spending time, socializing, establishing relationships and staying away from negative emotions, which, in turn, can result in depression (Gök, 2017; Korkmaz, 2017; Serin, 2011).

While there was a moderately significant negative correlation between internet and game addiction and the demanding/ destructive behavior sub-dimension of the school social behavior scale, a highly significant negative correlation was found between hostile/irritable behaviors, antisocial / aggressive behaviors and antisocial behavior sub-dimensions. Based on these findings, it can be concluded that the increase in internet/game addiction leads gifted children to develop and demonstrate anger, hostile and aggressive behaviors and result in a decrease in their empathic tendencies. Indeed, empathic tendencies of gifted children are an effective variable in anger control (Doğan, Üngüren, \&Algür, 2010; Silverman, 1994). The 
relevant literature has documented that the IQ scores of gifted children who do not receive the necessary social support and emotional support from their environments decrease (Webb, Meckstroth, \&Tolan, 1994)and their motivation is negatively affected in the process, which also increases their computer and game addiction (Yavuz, 2018).

\section{Conclusion}

In conclusion, it was observed that the internet and game addiction scores of the gifted boys in the study were higher than those of girls in terms of sub-dimensions and total scores. On the other hand, in terms of school social behaviors, the findings showed that gifted girls achieved higher scores than boys in terms of sub-dimensions and total scores. Additionally, we also observed that gifted children aged 10 and over got higher scores in terms of internet addiction sub-dimension and total scores compared to those 8-year-olds and 9-yearolds. Also, School social behavior did not show a significant difference according to the age variable. As the internet and game addiction scores of the gifted children increased, their interpersonal skills, self-management, academic skills and total social competencies, which are important components of school social competence, weakened. On the other hand, it was seen that the increase in the gifted children's internet / game addiction led to an increase in their demanding/destructive behaviors, hostile/irritable behaviors, anti-social / aggressive behaviors and antisocial behaviors. The findings of the current study can inform and guide professionals working with gifted children, teachers, researchers and families.

\section{SUGgestion}

Based on the findings and implications of the current study, it is recommended that future research can be conducted on student groups who are diagnosed as gifted but have not received any enrichment education. Also, a similar study can be designed with gifted and non-gifted students. Mixed methods research can also broaden our understanding of gifted children. Finally, further research can be carried out to assess the effectiveness of internet and game addiction training programs/seminars that will be directed at gifted students and their families.

\section{LIMITATION}

The current study also has some certain limitations. The first and second limitation of the study is about the structure and the method of its sample. When the limitation related to the structure of the sample is handled, the study was conducted with a group of gifted students who were provided enrichment education and the teachers working with them in the enrichment education programs which can affect the results. Additionally the convenient sampling method used in the study reduces the generalizability of the findings. The third limitation is that the internet and game addiction scale scores in the study were based on the participant students' own perceptions.

\section{References}

Ankara Kalkınma Ajansı (2016). Dijital oyun sektörü raporu, Retrieved August 20, 2018, fromhttps://www.ankaraka.org.tr/ archive/files/yayinlar/ankaraka-dijital-oyun-sektoru.pdf

Arı, M., \& Yaban, H. (2012). 9-11 yaşındaki çocukların sosyal problem çözme becerilerinde cinsiyet ve yaş farklılıkları. Eğitim ve Bilim, 37(164), 188-203.

Ayas, T., Çakır, Ö., \& Horzum, M. B. (2011). Ergenler için bilgisayar bağımlılı̆̆ 1 ölçeği. Kastamonu Eğitim Dergisi, 19 (2), 439-448.

Ayhan Bostanc1, G. (2020). 9-12 yaş arasındaki özel yetenekli çocukların bilgisayar bağımlılıkları ile sosyal beceri düzeyleri arasındaki ilişki. Unpublished master's thesis, Çağ Üniversitesi Sosyal Bilimler Enstitüsü, Mersin.

Bandura, A., \& Walters, R. H. (1963). Social learning and personality development. New York: Holt, Rinehart, Winston.

Bayraktar, F. (2001). Ergenlik döneminde internet kullanımının rolü. Unpublished master's thesis, Ege Üniversitesi Sosyal Bilimler Enstitüsü, İzmir.

Bilgiç, E. (2007). İlköğretim 1. kademede görülen zorba davranışların sınıf değişkenleri ve atmosferi algılamalarına göre incelenmesi. Unpublished master's thesis, Çukurova Üniversitesi, Adana.

Bleeker, M. M., \& Jacobs, J. E. (2004). Achievement in math and science: Do mothers' beliefs matter 12 years later? Journal of Educational Psychology, 96(1), 97-109.

Bozdağ, F., \& Ağaoglu, O. (2019). Özel yetenekli lise öğrencilerinde bilgiye ulaşmada internet kullanım düzeylerinin incelenmesi. Bilim Armonisi, 2(2), 5-13.

Caplan, S. E. (2005). A social skill account of problematic Internet use. Journal of Communication, 55(4), 721-736.

Clark, B. (2008). Growing up gifted. (7th ed.) Upper Saddle River, NJ: Prentice Hall.

Çeliker, V. B. (2020). 6. ve 7. sınıf öğrencilerinin internet bağımlılığg ile sosyal beceri düzeyleri arasındaki ilişki. Unpublished master's thesis, Maltepe Üniversitesi Lisansüstü Eğitim Enstitüsü, İstanbul.

Davis, G.\& Rimm, S. (2004). The cultural underachievement of females; Education of the gifted and talented. (5th ed). Massachusets: Allyn and Bacon.

Dengiz, N. A. (2014). Üstün zekalı ve üstün yetenekli çocuklarda algılanan sosyal destek düzeyinin benlik saygısına etkisinin incelenmesi.Unpublished master's thesis, Akdeniz Üniversitesi Eğitim Bilimleri Enstitüsü, Antalya.

Doğan, A. (2013). İnternet bağımlılığı yaygınlığı. Unpublished master's thesis, Dokuz Eylül Üniversitesi Eğitim Bilimleri Enstitüsü, İzmir.

Doğan, H., Üngüren, E., \& Algür, S. (2010). Öfke ve empati ilişkisine yönelik otel zincirinde bir araştırma. Çukurova Üniversitesi Sosyal Bilimler Enstitüsü Dergisi, 19 (3), 277-298.

Eccles, J. S. (1994). Understanding women's educational and occupational choices: Applying the Eccles et al. model of achievement-related choices. Psychology of Women Quarterly, 18(4), 585-609. 
Elcik, F. (2015). Üstün yetenekli öğrencilerin çevresinden algıladıkları sosyal destek düzeyi ile sosyal duygusal becerileri arasındaki ilişki.Unpublished doctorate dissertation, Dumlupınar Üniversitesi, Kütahya.

Eren, F., Ömerelli Çete, A., Avcil, S., \& Baykara, B. (2018). Üstün Yetenekli Çocuklarda ve Ailelerinde Duygusal ve Davranışsal Özellikler. Archives of Neuropsychiatry/Noropsikiatri Arsivi, 55(2), 105-112.

Erwin, P. G. (1993). Friendship and peer relations in children. England: Wiley.

George, D. ve Mallery, M. (2010). SPSS for windows step by step: A simple guide and reference, 17.0 update (10a ed.) Boston: Pearson.

Gök, A. Y. (2017). Ergenlerde problemli internet kullanımı, kişilik özellikleri ve sosyal beceri arasındaki ilişkinin incelenmesi. Unpublished master's thesis, Marmara Üniversitesi Eğitim Bilimleri Enstitüsü, İstanbul.

Gürbüz, T., Yıldırım, S., \& Özden, M. Y. (2001). Öğretmen adaylarının çevrimiçi ve geleneksel bilgisayar okuryazarlığ derslerinde bilgisayara yönelik tutumlarının karşılaştırılması: Bir durum çalışması. Eğitim ve Bilim, 26 (119), 49-56.

Ha, J. H., Kim, S. Y., Bae, S. C., Bae, S., Kim, H., Sim, M., ... \& Cho, S. C. (2007). Depression and Internet addiction in adolescents. Psychopathology, 40(6), 424-430.

Horzum, M.B. (2011). İlköğretim Öğrencilerinin Bilgisayar Oyunu Bağımlılık Düzeylerinin Çeşitli Değişkenlere Göre İncelenmesi. Eğitim ve Bilim, 36 (159), 56-68.

Irmak, A. Y., \& Erdoğan, S. (2016). Ergen ve genç erişkinlerde dijital oyun bağımlılığı: güncel bir bakış. Türk Psikiyatri Dergisi, 27(2), 128-137.

Jensen, E. (2000). Brain-compatible learning. California: Jensen Learning Corp.

Kahriman, İ. (2002). Adolesanlarda aile ve arkadaşlardan algılanan sosyal destek ile benlik saygısı arasındaki ilişki. Unpublished master's thesis, Atatürk Üniversitesi, Erzurum.

Kaplan, A. (2008). Raven'ın İlerleyen Matrisler Plus Testinin 12-13 yaş çocukları üzerinde geçerlik, güvenirlik ve ön norm çalışmalarına göre üstün zekâlı olan ve olmayan öğrencilerin mantıksal düşünme yeteneklerinin karşılaştırılması. Unpublished master's thesis, İstanbul Üniversitesi Sosyal Bilimler Enstitüsü, İstanbul.

Karasar, N. (2014). Bilimsel araştırma yöntemi "kavramlar ilkeler teknikler"(26. Baskı) Ankara: Nobel.

Kısa, Ö. (2018). Ortaokul öğrencilerinde yalnızlık ve sosyal beceri düzeyleri ile internet bağımlılığı arasındaki ilişkinin incelenmesi. Unpublished master's thesis, Kırklareli Üniversitesi Sağlık Bilimleri Enstitüsü, Kırklareli.

Király, O., Griffiths, M. D., King, D. L., Lee, H. K., Lee, S. Y., Bányai, F., Zsila, Á., Takacs, Z. K., \& Demetrovics, Z. (2018). Policy responses to problematic video game use: A systematic review of current measures and future possibilities. Journal of Behavioral Addictions, 1-15.

Koçak, S. S. Üstün yetenekli çocukların dijital oyunlara yönelik görüşlerinin incelenmesi. Journal of Gifted Education and Creativity, 6(2), 87-102.

Kokot, S. (2012). Help! Our child is gifted.Republic of South Africa: Radford House Publications.

Korkmaz, N. (2017). Lise öğrencilerinde internet kullanımının başarı, yalnızlık ve depresyon düzeyleri ile ilişkisi, Unpublished master's thesis, Üsküdar Üniversitesi Sosyal Bilimler Enstitüsü, İstanbul.

Kothari, C. R. (2004). Research methodology: Methods and techniques. New Age International.

Köroğlu, İ. Ş. (2014). Üstün yetenekli çocukların sosyal medya kullanım motivasyonları. Unpublished master's thesis, İstanbul Ticaret Üniversitesi Sosyal Bilimler Enstitüsü, İstanbul.

Kuru, A. (2018). Ön ergenlik dönemindeki üstün zekalı gençlerin empati algısının benlik saygısına etkisinin incelenmesi. 1 . Uluslararası Eğitim ve Sosyal Bilimlerde Yeni Ufuklar Kongresi Bildirileri. İstanbul. 58-70.

Loton, D., Borkoles, E., Lubman, D., \& Polman, R. (2016). Video game addiction, engagement and symptoms of stress, depression and anxiety: The mediating role of coping. International Journal of Mental Health and Addiction, 14(4), 565-578.

Marland Report (1972). Education of the gifted and talented: Report to the Congress of the United States by the Commissioner of Education. Washington, DC: U.S. Government Printing Office.

MEB (2016). Bilim ve Sanat merkezleri yönergesi.Retrieved May 24, 2018, fromhttps://orgm.meb.gov.tr/meb_iys_ dosyalar/2016_10/07031350_bilsem_yonergesi.pdf

Morahan-Martin, J., \& Schumacher, P. (2000). Incidence and correlates of pathological Internet use among college students. Computers in Human Behavior, 16(1), 13-29.

National Institute on Media and the Family (2005). Computer and video game addiction. Retrieved May 5, 2018, from http://www. mediafamily.org/facts/facts_gameaddiction.shtml

Ogurlu, U., Kahraman, S., \& Kayaalp, A. (2021). Computer game addiction in gifted students and non-gifted children: A caution for technology-oriented stem activities. Journal of Education in Science, Environment and Health, 7(2), 128-138.

Olweus, D. (2005). A useful evaluation design, and effects of the Olweus Bullying Prevention Program. Psychology, Crime \& Law, 11(4), 389-402.

Özen, Y., Gülaçtı, F.\& Çakılı, Y. (2004). Eğitim bilimleri ve internet. Doğu Anadolu Bölgesi Araştırmaları, 52-57.

Özgün, E., V. (2021). Bilgisayar oyunu oynama davranışının lise öğrencilerinin temel psikolojik ihtiyaçları ile ilişkisi. Unpublished master's thesis, Ankara Üniversitesi Eğitim Bilimleri Enstitüsü, Ankara.

Özhan, S. (2011). Dijital oyunlarda değerlendirme ve sınıflandırma sistemleri ve Türkiye açısından öneriler. Aile ve Toplum, 7(25), 21-33.

Reis, S. M., \& Hébert, T. P. (2008). Gender and giftedness. In Handbook of giftedness in children (pp. 271-291). Boston: Springer.

Renzulli, J. S. (1999). What is thing called giftedness and how do we develop it? A twenty-five year perspective. Journal for the Education of Gifted, 23(1), 3-54.

Rinn, A. N., Reynolds, M. J., \& McQueen, K. S. (2011). Perceived social support and the self-concepts of gifted adolescents. Journal for the Education of the Gifted, 34(3), 367-396.

Sayı, A. K., \& Emir, S. (2013) Farklılaştırılmış yabancı dil öğretiminin üstün zekalı öğrencilerde erişiye, eleştirel düşünmeye ve yaratıcılığa etkisi. Unpublished doctorate dissertation, İstanbul Üniversitesi Sosyal Bilimler Enstitüsü, İstanbul.

Serin, N. B. (2011). An examination of predictor variables for problematic intrnet use. The Turkish Online Journal of Educational Technology, 10 (3), 54-62. 
Sevgili Koçak, S., \& Kan, A. (2019). Sosyal duygusal beceri, arkadaşlık niteliği ve yalnızlık düzeyi arasındaki ilişkilerin incelenmesi: özel yetenekli öğrenciler üzerine bir araştırma. Electronic Turkish Studies, 14(7), 3939-3952.

Sicilia, M.\& Palazon, M. (2008). Brand Communities on the internet, A Case Study of Coca-Cola's Spanish Virtual Community. Corporate Communications An International Journal, 13(3), 255-270.

Silverman, L. K. (1993). Counseling the gifted \& talented. Denver, Colorado: Love Publishing Company.

Silverman, L. K. (1994). The moral sensitivity of gifted children and the evolution of society. Roeper Review, 17(2), 110-116.

Sternberg, R. J. (2003). Wisdom, intelligence, and creativity synthesized. England: Cambridge University Press.

Stockdale, L., \& Coyne, S. M. (2018). Video game addiction in emerging adulthood: Cross-sectional evidence of pathology in video game addicts as compared to matched healthy controls. Journal of Affective Disorders, 225, 265-272.

Sucu, İ. (2012). Sosyal medya oyunlarında gerçeklik olgusunun yön değiştirmesi: smeet oyunu örneği. Gümüşhane Üniversitesi İletişim Fakültesi Elektronik Dergisi, 1 (3).

Sureda Garcia, I., López Penádes, R., Rodriguez Rodriguez, R., \& Sureda Negre, J. (2020). Cyberbullying and internet addiction in gifted and nongifted teenagers. Gifted Child Quarterly, 64(3), 192-203.

Şenormanc1, Ö., Şenormancı, G., Güçlü, O., \& Konkan, R. (2014). Attachment and family functioning in patients with internet addiction. General Hospital Psychiatry, 36(2), 203-207.

Taşdemir, L. (2017). Özel yetenekli öğrencilerin bilgisayara yönelik tutumları ve teknoloji ile kendi kendine öğrenmeleri arasındaki ilişkinin incelenmesi. Unpublished master's thesis, Gazi Üniversitesi Eğitim Bilimleri Enstitüsü, Ankara.

Timisi, N. (2003). Yeni İletişim Teknolojileri ve Demokrasi, Ankara: Dost Kitabevi.

Totan, T. (2008). Ergenlerde zorbalığın anne, baba ve akran ilişkileri açısından incelenmesi.Unpublished master's thesis, Abant İzzet Baysal Üniversitesi, Sosyal Bilimler Enstitüsü, Bolu.
TÜİK (2020). Hanehalkı bilişim teknolojileri (bt) kullanım araştırması.Retrieved April 23, 2017, fromhttp://www.tuik.gov. tr/PreTablo.do?alt id $=1028$

Türkyılmaz, M. İ., \& Pekdoğan, S. (2019). 6-7 yaş çocuklarda sosyal davranışv ve okula hazırbulunuşluğun bazı değişkenler açısından incelenmesi. OPUS Uluslararası Toplum Araştırmaları Dergisi, 14(20), 133-160.

Usta, A. (2016). Üstün zekâlı ve yetenekli öğrencilerde internet bağımlılığının farklı değişkenlere göre incelenmesi.Unpublished master's thesis, Necmettin Erbakan Üniversitesi, Konya.

Ülger, B. B., \& Çepni, S. (2020). Evaluating the effect of differentiated inquiry-based science lesson modules on gifted students> scientific process skills. Pegem Eğitim ve Öğretim Dergisi, 10(4), 1289-1324.

Üstünel, H. (2008). Üstün zekâlı öğrencilerin PC oyun tercihlerinin akademik başarılarına etkileri. Unpublished master's thesis, Marmara Üniversitesi Fen Bilimleri Enstitüsü: İstanbul.

Wang, W. E. I. (2001). Internet dependency and psychosocial maturity among college students. International Journal of HumanComputer Studies, 55(6), 919-938.

Webb, J. T., Meckstroth, B., \& Tolan, S. (1994). Guiding the gifted child: A practical source for parents and teachers. Scottsdale, AZ.

Yalçın, H., \& Duran, Z. (2017). Çocukların iletişim araçları ve internet kullanma durumu ile aile-çocuk internet bağımlılık düzeyleri. Electronic Turkish Studies, 12(23),219-236.

Yalçın, H., Guvener, E., \& Kasal, D. (2020). Relationship between gifted children's internet gaming addiction and quality of life. European Journal of Special Education Research, 6(4).

Yavuz, O. (2018). Özel yetenekli öğrencilerde internet ve oyun bağımlılığı ile algılanan sosyal destek düzeylerinin incelenmesi. Yaşam Becerileri Psikoloji Dergisi, 2(4), 281-296.

Young, K.S. (2007). Cognitive behavior therapy with internet addicts: Treatment outcomes and implications. Cyber Psychology \& Behavior, 10 (5), 671-679.

Yukay-Yüksel, M. (2009). Okul sosyal davranış ölçeklerinin (OSDÖ) Türkçeye uyarlanması. Kuram ve Uygulamada Eğitim Bilimleri, 9(3), 1605-1650. 